continuity established from cell to cell, but that the phenomenon is of much zider, if not of universal occurrence." Kew, September 7 W. T, Thiselton Dyer

\section{A Plea for the Experimental Investigation of some Geological Problems}

THE subject of terrestrial physics involves the study of such a large number of phenomena that it is quite comprehensible that any one investigator must devote himself to only one or two branches of it at the most. The consequence of this is that from time to time some section of this extensive field of research is for a period neglected. Such is rcally the present state of experimental geology, and especially that branch relating to movements of the earth's surface.

Disturbances perceptible at the terrestrial surface may be looked upon as niade up of three very distinct groups: first we have actual upheaval or depression of comparatively large tracts of land. Secondly, we have true earthquakes, which probably are dependent upon a variety of circumstances, as, for instance, the snapping of a rocks stratum brought to the limit of its flexibility in consequence of the first group of movements; or the formation and injection of fissures by igneous mattcr. Lastly, there exists a series of small disturbances imperceptible to our senses and even to ordinary instruments of earthquake measurement, and only diccoverable by special delicately constructed apparatus. They seem to be dependent upon a variety of causes, amongst which are those of the two former groups, together with changes dependent upon or in relation with barometric pressure, tidal action, temperature of the air, rainfall, \&c.

The upheaval or depression of our earth's surface is the very basis of geological science, for it is in consequence of this that rociss have been brought within the reach of investigation, and that our globe has some dry ground upon which we can live, instead of one continuous expanse of ocean. The changes of level were suppo ed by the cataclysmic school of geologists to occur suddenly, bringing about entirely new distributions of land and water in a short period of time. Lyell, as the leader of the uniformists, laboured all his life to prove that these upheavals were in the main a slow and gradual process, extending over long periods of time. One of this author's examples which he brought forward in the argument with as much skill and force as an accomplished counsel would have done in pleading a cause, was the renowned (so-called) temple of Serapis at Pozzuoli. This building wai for half a century the subject of almost innumerable books and pamphlets, some of which show a vast amount of ingenuity. None perhaps were more elaborately worked out than the volume of researches on the phenomena of this building and the neighbouring coast from Gaeta, around the whole guif of that name, together with the Gulf of Naples, to the Punta Campanclia. The author there brings forward a large amount of genuine evidence to show that during the last 2000 years the whole coast has been in a state of oscillation, so that the relative change of level of the land and sea has been as much as $12 \mathrm{~m}$. So far as Niccolini's investigations were capable of being carried out, abundant evidence showed that about the second or third century B.C. the coast line commenced to descend, and continued to do so gradually until the soth or $\mathrm{I}$ ith centuries, when elevation took place firr nearly $6 \mathrm{~m}$., till in the sixtcenth century, when depression again set in. This depression is now going on in a remarkably rapid manner. I have in my pos:ession an engraving of the temple of Scrapis, in which the base of the three columns stand; on the upper antique pavement of the building, which is perfectly dry. This is dated 1810 . In Niccolini's work is another drawing, made in 1845 , in which water had commenced to collect, so that it was necessary to wade about. In 1879 a layer of earth of over a metre had been spread over the floor to make access convenient, the standing column being surrounded by brickwork cylinders, and standing in water of over a metre in depth. The ground was then dry, but from time to time when I visiter the building I found puddles commenced to collect, which at last grew so large and deep that lately an additional layer of sea-sand has been added to further raise the level. Similar variations have been observed in other parts of both of the Mediterranean and Adriatic coasts of Italy, which all seem to indicate that this geologically speaking young peninsula has not yet stopped growing.

But if the coast-lines are altering, are we not justified in supposing that the axial ridges of the Apennines are not doing so also, even in all probability to a far greater extent, though from the want of a fixed datum-line, such a the səa may afford, we are unable to apprceiate the amount of disturbance? It is not likely that this change of levels exceeds $50 \mathrm{~m}$. in historic times in Italy.

If we even accept the recent reports from Spain as gross exaggerations, we cannot well believe them to be pure inven tions when changes of $400 \mathrm{~m}$. are spoken of, which conld hardly be asserted without some foundation of truth.

Now, are we not bound in some way to investigate these phenomena, which involve the very principles of geological science? It is strange, but true, that around the Gulfs of Naples and (iacta no instruncht exists for registering the relative level of the sea, nor do there exist any marks on rocks that are officially looked after. During the earthquake of Ischia of 1883 it is not known whether any disturbance of the sea took place, and we are perfectly ignorant of the rate and other characters in the change of the relative levels of the land and sea.

But putting aside this gradual elevation or subsidence, are we not permitting to slip by one of the mo t remarkable examples of quick elevation and depression which from the accounts that now reach us are taking place in Spain? Were the reports as to changes of three and four hundred metres true, we should be compelled, to a certain extent, to accept in part the teachings of the cataclysmists.

It seems regrettable that England, which is the mother country of geology, should allow such an opportunity as the Spanish peninsula now presents for the investigation of important terrestrial disturbance; to slip by. Even if the earthquakes themselves are not studied, little expense of time or money would be necessary to chronicle at least the principal phenomena now in progress, which the Royal or some other Society might well take up.

H. J. Johnston-LAVIs

\section{Iridescent Clouds}

The letters of Prof. Piazzi-Smyth and Mr. J. Edmund Clark (vol. xxxi. p. $\mathrm{r}_{4} 8$ ) on iridescent clouds, while interesting, do not, if I mistake not, record any new phenomena. The deseriptions given agree very well with that of a phenomenon which I have observed here several times, and which is described in Herschel's "Meteorology," p. 225. Here the phenomenon is ustally seen before the approach of the monsoon, and is looked upon as a sign of its being near at hand. Under these circum. stances it can hardly be admitted that they have any connection with the cloud glows of which so much have been written, and which, as observed from the top of D dabetta ( 8600 feet), are as brilliant as ever when the atmosphere is sufficiently dry.

It may perhaps still be of interest to some to know that observations made on the spectrum of the sun when seen through mists from the same hill-top, showed that the spectrum of the "green sun" can be completely reproduced by superposing the spectra of sunlight passing through a mist and through a thick layer of moist air; and it is probable that all cases in which the sun has been seen green can be thus explained.

The Christian College, Madras, Janua y I

\section{Science Teaching in Schools}

In the discussion as to the teaching of science I have failed to find any distinct cxpression of an element in the subject which has for ycars scemed to me of the highest importance, and to which I should like with your permission to call attention. In those of our schools where science is taught it is almost always taken up late in the boy's carcer, often when he is passing from the lower to the upper school. This I feel surc is a mistake. Think for a moment of the process of evolution of that phenomenon--the English schoolboy. In too many cases he passes through the first, second, and third forms of a school, learning little more than the habit of diligent plodding, and developing littlc more than the art of storing away an unheardof quantity of dry fact: IIe learns, for instance, page after page of grammar rules; he learns rules for making numerical transformations; he even learns in the same fashion answers to questions that examiners are known to set for the purpose of finding out whether the pupil has been intelli $i_{5}$ ently taught The habils so acquired are valuable, but they are acquired at the risk of sacrificing the boy's freshness, and with the subjugation of his habit of independent reasoning. $\Lambda \mathrm{fter}$ several years of such training the herald of science comes forward with such a 